\title{
Happy birthday Richard Bing!
}

\section{Martin Gottwik, Georg Ertl, Michael Böhm for the Board of the Deutsche Gesellschaft für Kardiologie/Herz-Kreislaufforschung (DGK, German Cardiac Society)}

\author{
Martin Gottwik
}

Published online: 17 November 2009

(C) Springer-Verlag 2009

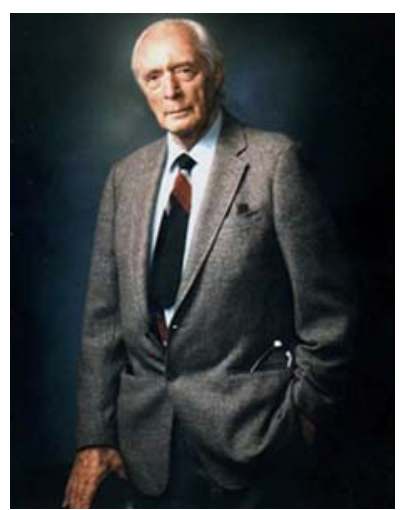

Congratulations to Richard J. Bing MD, honorary member the German Cardiac Society, who will celebrate his 100th birthday on October 12, 2009.

Richard Bing is an exceptional basic scientist and one of the pioneers in cardiac catheterization. He promoted the invasive studies of congenital heart disease in 1945, together with A. Blalock and $\mathrm{H}$. Taussig at the Johns Hopkins Hospital in Baltimore [1]. Combining his deep knowledge on cardiac physiology and skills in cardiac catheterization, he studied in depth cardiac perfusion and metabolism. His oeuvre exceeds 500 scientific publications; some of them are keys to the understanding of pathological cardiac anatomy, function and metabolism. He was called one of the "Founding Fathers of Experimental Cardiology" [2]. Indeed, he is the founder of the International Society for Heart Research, the Journal of Molecular and Cellular Biology (1965), and the Journal of Applied Cardiology (1986). Over the last 20 years, he devoted his writing to the history of cardiology [3]. He is recipient of important scientific prices, honorary doctorates and honorary memberships of international cardiovascular societies.

Aside from his medical research, Richard Bing is a novelist [2] and a recognized musician and composer. He has started composing as a grammar school boy influenced by Carl Orff and Richard Strauss.

M. Gottwik ( $\square)$

Institut für Herzinfarktforschung, Bremserstr. 79,

67063 Ludwigshafen, Germany

e-mail: mug.gottwik@t-online.de
He has written more than 200 musical pieces, among them his "Missa", first performed in the Stephansdom in Vienna, and his "Magnificat", first performed in the monastery St. Florian, in UpperAustria, where Anton Bruckner had been active as an organist and composer for many years. Those of us who were able to attend the fall meeting of the German Society of Cardiology in Gießen, in 1996, vividly recall his presence on the stage and the performance of one of his recently composed chamber music pieces.

Above all, Richard Bing is an exceptional and exemplary humanitarian person: he was born in Nürnberg Germany. He attended the Conservatory of Music in his hometown before he moved for his medical training to Vienna, Berlin, and Munich where he graduated in 1934. As a member of a prominent Jewish family in Nürnberg, he had no future in Germany and faced racist prosecution after Hitler and the "Nazionalsozialistische Arbeiterpartei" had established their regime in 1933. He made his way through Switzerland, Denmark and finally to the United States of America. In spite of this individual history, his efficiently helped to rebuild German cardiovascular science after the Second World War and the devastation of Germany. He supported young German Scientists of Austria and Germany and introduced them to modern science and medicine in his institutes in the USA. Many returned to Europe; some of them are still active, holding important clinical and academic positions.

As a sign of their gratefulness and devotion, a number of physicians in Nürnberg have organized for his birthday a concert with works of Richard Bing's Musik in the Frauenkirche where Richard, as a boy, was first exposed to Sebastian Bach's (personal communication) music. Everyone who knows Richard Bing and has read his publications of the year 2009, can imagine that, even from distance, he takes an active part in the preparations of the concert. The German Cardiac Society will honour Richard Bing with the GCS Gold Medal (Goldene Ehrennadel). Congratulations Dr. Bing.

\section{References}

1. Vandam LD (1989) Ferment in Baltimore in the forties. J Appl Cardiol 4:345-349

2. Cheng TO (2009) Happy 100th birthday to Dr. Richard Bing. Int J Cardiol 137:87-101

3. Bing RJ (1990) Evolution in cardiology: triumph and defeat. Perspect BiolMed 34:1-16 